Erschienen in: Manz, Stefan/Musolff, Andreas/Long J.J./Šarić, Ljiljana (Hrsg.): Discourses of Intercultural Identity in Britain, Germany and Eastern Europe. Journal of Multilingual \& Multicultural Development, Vol. 25, 5\&6. S. 497-511 - Colchester : Routledge, 2004.

\title{
Americanisation and the Discourse of Guilt in Germany, 1945-1955
}

\author{
Heidrun Kämper \\ Institut für deutsche Sprache, Mannheim, Germany
}

Rather than originating in the post-1945 period, the Americanisation of the German language represents the post-war transformation of a gradual anglicisation of German which began in the 18th century with the expansion of English industry and trade. The influence of American English on German began after World War I, and intensified under the specific political and societal conditions prevailing in Germany after 1945. The Americanisation of the German language cannot therefore be reduced to the general phenomenon of westemisation that has affected all Eurasian countries (and national languages) since World War II. Rather, it is a development that has its roots in German-American relations of the decade between 1945 and 1955. This decade saw not only the creation of the Federal Republic of Germany, but also intensive debate among German intellectuals and the political elite about Germany's past, present and future, and about German guilt and identity. This article analyses the Americanisation of the German language as an aspect of this German guilt discourse and as an inlegral part of the (re-)establishment of German identity. Methodologically the article is related to a linguistically orientated history of mentalités.

Keywords: German language, post-war history, German-American relations, mentalities, discourse history

\section{Methodological Remarks}

The Americanisation of the German language under the specific political conditions of the decade between 1945 and 1955 can be seen not only as a part of the history of the German language or as an aspect of the German language system, but also as part of the history of mentnlités. I understand mentalité as the whole set of manners and habits of thinking and feeling which determine a certain collective at a certain time. ${ }^{1}$ Mentalite's become manifest in the way people act, ${ }^{2}$ and speaking (and writing) are ways of acting. Writing the history of mentalites thus consists in describing and analysing the mind-set of a group as this mind-set manifests itself in speech and writing (Hermanns, 1995: 96). Mentnlités can be seen as a mirror of social and cultural experiences in the context of a specific living environment (Kuhlemann, 1996: 203). In what follows, I assume a correspondence between the particular mentalité of postwar Germany and the influence of American English on the German language in the early post-war period. In other words, the attitude of the Germans towards their American liberators and occupiers was a vital component of their receptiveness to the American language. Success or failure of any cultural interference depends less on governmental decrees than on attitudes, on social circumstances concerning the opinions that each of the groups involved has of the others. In this article, I consider some of the linguistic changes against the 
background of German attitudes towards the Americans. Following on from this, I link this linguistic change with German post-war conceptions of national guilt and national identity.

\section{Past History}

In respect of the whole complex of the Americanisation of the German language, one can distinguish at least three main phases of the EnglishGerman linguistic relationship. The first phase is the 'prehistory', namely the earliest English and American linguistic influences in the 18th century (see below). The second phase might be termed 'from unconditional surrender to unconditional adherence', by which I mean the appropriation of the occupiers' language between 1945 and 1955 (the main subject of this article). The third phase, which falls outside the scope of this article, concerns Americanisation as a phenomenon of globalisation, westernisation and internationalisation as these have taken place since about 1955.

The prehistory of the American influence on the Cerman language is the history of the development of the English language with regard to its image in Germany. Although it is nowadays almost impossible to differentiate unequivocally between American and British English, things seem to have been clearer in earlier times. Today, there are very few words that are unambiguously either American or British, and any attempt at differentiation is complicated by the fact that British English is itself strongly influenced by American English. While the unambiguous differentiation of Americanisms and Britishisms is problematic, we can be sure of what we can call the Americanisation of Anglicisms.

Since England was the global player in economic and political terms, it was British English that was influential in the 18 th and 19 th centuries (see Galinsky, 1977; Kämper, 2001). From the late Enlightenment, English developed into the lingua franca of Europe, the language of liberty, democracy, modernisation, economic and technical progress. Nevertheless, the influence of English was sporadic. A first wave of linguistic borrowing from English took place in the 19th century, when England was the model in terms of industry and trade (Kartell, Trust, Partner, Stnudhrd), traffic and transport (Lokomotive, Tender, Tummel, Viadukl, Waggon, Express), the press (Leitartikel, Essay, Reporter, Intervicu), politics and democracy (Demonstration, radikal, lynchen, Stimntoidh, Mob, Streik, Imperialismus), social life (Gentlemin, Snob, Dandy, Solfmademan, Club, fair, allright, tiptop, Culawony, Sinoking, Breceles, Becfste'ak, Tonst, Pudting, Bar, Whisky, Clurry, Cocklail, Sport, Temis, Hockey, Picknick, Flirl). English words in 19th-century German also include Koks ('coke'), Strcik ('strike'), Klub ('club'), Keks ('cakes'), Frnck ('frock'). As can be seen, these forcign words became integrated into the graphemic system of the Gernan language. Should this be read as a sign of strong Cerman identity at a time when the German menlalile was marked by a high degree of nationalism? This orthographic integration process declines after 1945. Since then, more and more English or American words have kept their English or American appearance as they have been absorbed into the German language system. 
We can assume that the entrance of American English on the German stage took place around the beginning or middle of the 19th century. English lessons in German schools began around 1850, and provided favourable conditions for the takeover process of American words. At this time the traditional German image of America was created by popular German and American writers like Karl May and Friedrich Gerstäcker, Mark Twain and Jack London. Red Indians, cowboys and gold diggers were the widespread American stereotypes, and to an extent they still are. To this may be added the image of American English as the language of the promised land, which emigrants had to learn before they left their homelands and which represented all their hopes. Amerika, das Land der muegrenzten Mögliclikeiten 'the country of unlimited possibilities' has been a German saying since 1902, when the America tourist Ludwig Max Goldberger, asked by an associated press journalist about his impressions of the USA, coined it (see Büchmann, 2001: 420).

Another second distinct wave of American linguistic influence on German starts after the First World War, with one purist writing derisively of an Ameriknfimmel or 'American craze' (Zitgelschmid, 1935: 25). Since the 1920s, loan words like Film, Bestseller, Bluff, Jazz, Song, Foxtrott, Pullover, Manager, innken have been part of the German 'anguage.

So far, 1 have concentrated solely on the German language. But similar processes of linguistic exchange could be witnessed throughout the western world; the American German relationship was not exceptional. To talk about the special feature of the American-German relationship, we have to turn to the special circumstances of the immediate the post-war period. With respect to the Americanisation of the German language, this phase is the most interesting as it concerns a set of conditions of central importance for contemporary history as well as for the history of civilisation. Seen from the American perspective, a war was won, a whole national society had to be won over to peace and democracy, everything, the cities, the industries, the adininistration and, not least, the morale and spirits of the people, had been destroyed and had to be rebuilt - and all this in the shadow of crimes against humanity such as the world had never seen before.

\section{The Germans' Attitude fowards the Americans}

Frühling wurd's im deutschen Land... als von Süden, aus den Tälern, /herbewegte sich von Wählern/pomphaft ein zerlumpter Zug,/der zwei alte Tafeln trug.//Mürbe war das $\mathrm{Holz}$ von Stichen/und die Inschrift sehr verblichen,/und es war so etwas wie/Freiheit und Democracy. (Brecht 1948: 36-41)

Spring came to the German lands. when from the south, out of the valleys, came ceremoniously a ragged train of voters carrying two tablets. The wood was rotten and worm-infested, and the inscription bleached, and it read something like: Freedom and Democracy. 
This is the beginning of a poem by Bertolt Brecht, entitled Freilhit and Democrncy 'Liberty and Democracy'. Brecht published this poem in 1948, the year of his return to the Soviet zone, the zone where his political orientation paralleled that of the government. The poem deals with Cermany's post-war atmosphere. Churchmen and industrialists, teachers, doctors and scientists, journalists and honourable citizens, politicians, traders, judges and artists as weil as SS men, Nazi women, and informers - not only do they claim innucence, but they also call for, indeed, insist on Frrihteit und Denocracy, which is not only the title, but also the refrain of this long ballad.

... Für die Rüstungsindustrie/Freiheit und Democracy... auch für die Chemie/Freiheit und Democracy. . . Die SS. . Freiheit braucht auch sie,/ Freiheit und Democracy.

For the armaments industry, freedom and democracy... Also for the chemical industry, freedom and democracy... The SS, too, need their freedom, freedom and democracy.)

Now, why does Brecht use the English word dentocracy instead of German Demokratie? Not for what might be called technical reasons of meter or rhyme: Dimokratie and dimocracy both have the same four syllables and the same ending sound $/ \mathrm{e} /$. What Brecht does here is to express the view that democracy is a typically American arrangement. Although the Soviets also claimed - at least at a lexical level - to be democratising the Germans, jt was primarily an American task. It is the specifically American aspect of the core principle of democracy that became evident in the post-war period. ${ }^{3}$ And it is the western version of democracy that Brecht, as a communist, criticises. Beyond this, the Americans were the dominant occupying force. So the dominant form of this term is the English one. The English term is the one that would have been familiar to Germans at the time, the one whose sound they would have had in their ears. This would have applied even more to the returning exiles who had spent their time in the USA - even those of a communist persuasion, like Bertolt Brecht.

In the present context we can see this refrain as a literary aesthelisation of the German linguistic state in the early post-war period: it is an expression of a particular political, social and mental moment.

German's political position, as we know, was one of a lost war, of a nonexistent German state and of allied occupation. The text of the capitulation decree for a defeated Gernany reflected the political and the resulting linguistic reality: 'This Act is drawn up in the English, Russian, and German languages. The English and Russian are the only authentic texts.' (Act of Surrender, 1945: 14). The social condition was one of total destruction -- of cities, lives and livelihoods. The Germans' mental state, finally, was dominated by feelings of defeat and depression. Only very few, the so-called politicians of the first hour and intellectuals, had any sense of guilt. 'This sense of guilt was accompanied by the strategic intention of these politicians and intellectuals to find a new identity for the Germans. Their aim was the rehabilitation of the Germans in the eyes of the world. This was the stage on which the 'Americanization of the Germans and the German language' was played 
out. Assuming that Americanisation is a phenomenon of language and societal relations, linguistic Americanisation is a result of this political, social and mental post-war situation.

How did the Germans perceive the Americans? What did they perceive, and how did these perceptions manifest themselves linguistically? We can identify at least two modes of perception: the 'everyday life view' on the one side, and the intellectual and political view on the other.

\section{Everyday life view}

With regard to everyday life, the Germans perceived the occupying power in every sphere of their lives. Soldiers and civilians, newspapers and films, songs and magazines, books and stage plays, AFN, bilingual street signs, and governmental decrees - all sectors of life were determined by the Americans. And they ran counter to the Germans' initial fears. The Germans were aware of America's charity and support, helping them out of their worst misery, be it through CARE (which has been a German word since 1946) or through the Hoover Relief Programme for the benefit of 3.5 million German children. And the omnipresent Gl's were the polar ofposite of the Nazi propaganda version of American soldiers: they were polite and kind, especially towards children; they brought chocolate, coffee and cigarettes; in other words, they were 'friendly enemies'. The figure of the American GI is a post-war stereotype, or better a symbol, which represented the views of Germans - and in particular the views of the German 'Frauleins' (a w'ord which itself forms another postwar stereotype). The German writer Wolfgang Koeppen described this perception in his inportant post-war novel Tauben im Gras (Pigeons in the Grass):

Die amerikanischen Jungen waren dem Fräulein lieber als die deutschen Jungen. Die amerikanischen Jungen erinnterten das Fräulein nicht an das grämliche Zuhause. [...j Unı die amerikanischen ]ungen war Luft, die Luft der weiten Welt; der Zauber der Ferne, aus der sie kamen, verschönte sie. Die amerikanischen Jungen waren freundlich, kindlich und unbeschwert. Sie waren nicht so mit Schicksal, Angst, Zweifel, Vergangenheit und Aussichtslosigkeit belastet wie die deutschen Jungen.

The Franleins preferred American boys to German boys. The American boys did not remind the Franleins of the misery of home. There was air around the American boy's, the air of the big wide world; they were made beautiful by the magic of the distant lands from whence they came. The American boys were friendly, childish, and carefree. They were not burdened with any sense of fate, fear, doubt, the past, and hopelessness like the German boys. (Koeppen, 1980: 183; translation by the author)

This unconditionally affirmative view from the perspective of a German girl is a typical one. Yet in the very early post-war period, opinions were not uniformly positive; they wavered between respect and admiration on the one hand, and astonishment and suspicion on the other. Again Koeppen vividly 
illustrates the anxieties attached to American femininity and the multiracial nation of cur drivers from the German perspective:

Frauen, Frauen modisch und burschikos gekleidet, Frauen damenstolz und jungenhaft, Frauen in olivgrünen Uniformen, weibliche Leutnants und weiblichen Majore, keß geschminkte Backfische, sehr viel Frauen, dann Zivilangestellte, Offiziere und Soldaten, Neger und Negerimnen, sie alle gehörten zur Besatzung, sie bevölkerten den Platz, sie riefen, lachten, winkten, sie lenkten die schönen das Lied des Reichtums summende Automobile geschickt zwischen die schon parkenden Fahrzeuge. Die Deutschen bewunderten und verabscheuten den rollenden Aufwand.

Women, women dressed in fashionable and tomboyish clothes, women both boyish and ladylike, women in olive-green uniforms, female lieutenants and female majors, pertly made-up teenagers, many, many women, and on top of that civilians, officers and soldiers, negroes and negresses, they all belonged to the occupying forces, they populated the city streets, they shouted, laughed, waved, they skilfully steered the beautiful automobiles that hummed of wealth between the parked vehicles. The Germans admired and abhorred the unceasing expenditure. (p. 69; translation by the author)

They admired and abhorred - this may be the best characterisation of the ambiguous attitude of the German people towards the occupiers. It was the attitude of the very early post-war period, which soon changed into the solid conviction that the American occupation was the best thing that could happen to the Germans - in spite of curfore and off limits, automatic arrest and no fraternization, denazification, reeducation and ipestionnaire. These unpleasant governmental decrees might have structured the reality of post-war Germany, but German attitudes towards the Americans could not have been seriously affected. The unique conditions of the decade from 1945 to 1955 and the nearnormality of German-American relations since then determined the West German image of America in the post-war period. The Americans offered participation in a culture that identified happiness with consumption - a welcome legitimation of post-war German desires. Under these circumstances, American English became popular. It was promoted by youth culture, by the entertainment industry, by science, by tourism and business. The following are borrowings that entered the German language between 1945 and $1955 .^{4}$

\section{Life and lifestyle}

toasten (1945), Nachlklub (1947), Supermarkt (1948), Bollle Party (1949), Cocklailkleid (1954)

\section{Business}

Profi (1947), job (1949), Manngement (1949), Marklforschnng (1949), Dumping (1949), Boss (1949), Public Rolations (1951), Morketing (1952), Boom (1954), Rezession (1954) 
Music and entertainment

Comeback (1947), Quiz (1947), Band (1947), Hitparade (1947), Swing (1947), Kanal (1947), Sejjenoper (1949), Thriller (1949), Song (1949), Skript (1952), Background (1953), Starlet (1953), Big Band (1953), Discjockey (1953), Drummer (1953), Sound (1953), Jukebox (1954), lite (1954), Sciencefiction (1954), Sex and
Crime (1955)

\section{Fashion and cosmetics} Makeup (1947), New Look (1947), Look (1949), Bluejeans (1950), Sweater (1950),
Petticont (1954)

\section{Sports}

dopen (1947), Squash (1952), Basketball (1954), Rallye (1954), Foul (1954)

\section{Travelling/tourism:}

Nonstop- (1947), Charterflug (1949), trampen (1950), Motel (1953), Camining

\section{Science}

Radar (1946), Symposium (1947), Alommeiler (1947), Pipeline (1947), Renktor (1947), Programm (1947), Netzuerk (1949), Smog (1950), Stref3 (1952), Knowu-how
(1952), Transistor (1953), Tutorial (1954)

\section{Others like}

Color (1949), Teenager (1950), Layout (1954), Allroundman (1954), clever (1954).

\section{View of the elife}

Up to now I have discussed Americanisation at the level of everyday life and the attitude that the average citizen had towards the Americans. Now let us turn to the political and intellectual point of view. The Americanisation of the German language had a lot to do with the attitude of the German intellectuals towards the American occupying power. This attitude was again influenced by the German élite's self-assessment. They felt guility. We failed urir haben versagt is the common phrase of their self-accusation. Although many Germans considered the Americans as accuser judge, re-educator and ruler, there is no doubting the readiness of the German élites to reflect on and analyse Germany's guilt, or their scrious efforts to reintegrate Germany into the community of nations. This rehabilitation project played a major role in
their dealings with the Americans.

1945/46 my benevolent but also professionally correct American partner followed his instructions to the letter by trying to educate me, who was the Minister of Culture for Württemberg-Baden at the time, only then to concern himself with my education in German educational policy, and a fruitful mutual friendship developed because the important thing to him as well as to me was to achieve something; in his language: to make the

This is a quotation of the former German president Theodor Heuss. The German version of the decisive part reads: 'Denn ihm wie mir kam es darauf an, etwas fertig zu bringen; in seiner Sprache: to make the best of it'. 
Probably no official statement makes clearer the attitude of German politicians towards the American occupiers than this anecdote, which Theodor Heuss related in 1955. This story delineates important aspects of the early post-war German-American relationship: first the perception of the Americans obviously both as inexorable educators and as sensitive friends; second the beginning of a German-American friendship; third a sympathetic connection as a condition enabling the foreign language to influence German. This avowal manifests itself in Heuss's explicit reflection on language: 'in seiner Sprache: to make the best of it."

With regard to the attitudes of the political and intellectual élites, we have to be aware of some special conditions. The position of public figures in the early post-war period has been labelled 'waiting for the jeep'. This means that as early as May 1945 they were asked by the Allies to help and they could expect (or fear) to be picked up by American jeeps and to be brought, for example, to a pile of rubble that had once been the city hall. Their job was to assist in rebuilding the German state and society. Their names were noted on white lists as being undoubtedly clean and not contaminated with the brown plague' (i.e. involvement in Nazism).

These intellectuals and politicians knew that they had no choice: There was no alternative but to adopt democratic principles - aside from the fact that these 'men and women of the first hour' were in fact true democrats, albeit in the tradition of the Weimar Republic. They were filled with the democratic idea and the desire to turn Germany into a constitutional democratic society. ${ }^{5}$ For the intellectuals of an entire generation, the modern, open society of America, where things were freely discussed, was a revelation. And a participant of the first German Writers Congress in 1947 writes of those who came from America as part of the occupying force to fulfil the task of protecting Germany's literary culture, to stimulate it and to give it the form, in which alone it could once more become part of world literature again: the form of humanity, the form of democracy (Redslob, 1947: 451).

The newly elected first Chancellor of the FRG, Konrad Adenauer, affirmed in his first policy statement on September 20,1949:

After the complete collapse that National Socialism has brought upon us, the only way for the German people to achieve liberty and equality again is to ensure that they walk side by side with the allies on their onward and upward march. The only way we can attain liberty is by working in conjunction with the High Commission and try to enlarge our liberties and our spheres of responsibility piece by piece. (Adenauer, 1949a: 27)

To remove all doubt, western German politicians gave clear signals to their compatriots: the Americans are our rescuers, loyalty towards the Allies is the condition for Germany's reemergence. Konrad Adenaucr, in his aforementioned first policy statement, pays homage 'in this hour' to the USA 'with special thanks': 
I do not believe that at any time in history a victorious country has tried reco hanquished and to contribute to its reconstruction and recovery as the United States has done and still does with Germany. We believe, ladies and gentlemen, that history will see this behaviour of the United States as a greater feat than its efforts during the war. I know that in our times of bitterest misery, when hunger and need were all around, countless Americans helped us Germans in the most moving way and out of genuine personal sympathy and charity. (Adenauer, 1949b: 169)

A fruitfil mutual friendship, humanity, no other way, countless Americans helpet us, personal sympathy and charity - these phrases characterise the intellectuals' and politicians' attitude towards the Americans. And they make clear that Americanisation took place on different levels, on the mental, the intellectual, the political and the emotional level. It was an affair of real sympathy on the one hand, of cool calculation on the other. However, the Americanisation of Germany was also an expression of West Germany's integration into the western military alliance in the immediate post-war period. Checkpoinl is one of the lending words of this integration: 'fight against communism', 'WestBerlin', 'USA' are its key terms tha: reflect the concerns of contemporary politicians, similar to Eiserncr Vorhang 'iron curtain' and Kalter Kricg 'cold war'. They are Americanisms, and they thoroughly describe the post-war German condition - which in 1945 was also a thoroughly American condition.
Later borrowings from the political and military sphere include:

Schwarzer Mirkt (1946), Displacid Persons (1947), Gontlemen's Agrecenent (1947), Bummenrepublik (1947), Wassershofflombe (1947), Gl (1948), Lufturiicke (1948), Airlift (1949), Aggression (1949), A-Bombe (1950), Containment (1951), Goodwill (1951), Roll-brok (1951), multiatera: (1954), Erdrutsch (1954), fricdliche Korastenz
(1954), ABC-(1955).

These borrowings reflect the continued stabilisation of Germany's integration into the western bloc. The new geopolitical constellation assigned Germany a decisive political and strategic role. No other country determined the destiny of the Germans as much as the USA; but conversely, no other country affected America's destiny as much as Germany. ${ }^{6}$ As the hinge between east and west, Germany was the unique focus of American attention. But this is not the only
explanation for the influence of American English.

The need to evolve into a peaceful and democratic society was the primary condition for the Americanisation of Germany: Historians have maintained that this process of Americanisation is no more than part of a global process of modernisation, which is typical for all urbanised and industrialised societies. But this is not the case. A further special feature of the Americanisation of post-war Germany links the particular and unique German situation with linguistic reality, namely the question of German guilt and national
identity. 


\section{Identities - Mentalités}

The impact of Amcrican rule became obvious in the years immediately following 1945. It was intimately linked to National Socialism and its consequences. The Americanisation of the German language was carried out by the Germans and was one of several German strategies for overcoming the crisis of German national identity caused by the appalling crimes of the Nazi regime.

Germany was under allied occupation. So one of the most important expressions of German self-assessment was the perception of their position in relation to the American occupiers. Although it seems that politicians and intellectuals in particular had a certain degree of influence, they often deplored the fact that Germans were under foreign rule. Freie Sclhstbestimmnns 'free self-determination' is a post-war keyword that expresses the nain perceived deficit in post-war Germany. Their biggest problem was that they were at the mercy of the Allies. In 1945, the famous Gernan philosopher Karl Jaspers, for example, spoke of the 'dependence of all our acts on the will of the occupying forces, who liberated us from the National Socialist yoke' (Jaspers, 1945: 3), and in 1946 Theodor Heuss felt that living in Germany as a German was 'not like living in the state of free democracy but like being at the mercy of the allies' (Heuss, 1946: 213).

Nevertheless, the Germans knew that they had no right to complain. They knew that they started and lost the war, and huge crimes against humanity made the Germans a guilty nation - reasons for post-war German discourse to establish the causes. One interpretation pattern claims that specific traits of the German mentalite were to blame for the rise and endurance of National Socialism. These traits include dispositions towards obedience, militarism and aggressive nationalism. ${ }^{7}$ Such self-perceptions contrasted with Germans' view of the Americans. From the German perspective, Americans represented a mentalite that they thenselves secretly desired. Their being victors corresponded to their dispositions towards liberty, carctreeness and realism. Conversely, the key features of the German minlalite corresponded to their situation as a defeated and guilty nation. Enst Wiechert, the famous Christian author, who was imprisoned in the Buchenwald concentration camp by the Nazis for several months, ${ }^{\circ}$ described for example his new guests:

We will always remember those weeks with gratitude, weeks of unrest when morality was suspended, but also weeks of wonderful humanity, the feeling of being protected, understanding, a immense readiness to help. Among them [the American soldiers] were loud and quiet types, boystrous and retiring types, the highly educated and the barely literate. They drank a lot and were in many things less inhibited than we were used to. But they never violated the bounds of decency. They were like big kids, but they were good-natured, happy, and even grateful kids. (Wiechert, 1949: 379)

This kind of description of the American soldiers is a typical trait of German post-war discourse. Americans were seen as carefree children, as boyish, a judgement that carried with it both a basic sympathy towards typical 
American traits and, at the same time, a certain envy of these traits, which were the polar opposites of the stereotypical German mintalitc: 'The Americans are occasionally coarse, naive, but all in all - aside from the schematic, missionary task of denazification - generous and constructive' a commentator wrote in his diary in 1946 (Benz, 1984: 100). Naive seems to describe a very typical trait that must have been remarkable for the Germans. It is the stereotype that expresses the Germans' view of the Americans. Another contemporary talks of the 'absolute otherness' of the American
soldiers:

We call them - relative to us - naive. This has nothing to do with their level of culture, but with a certain youthful unpretentiousness, robustness, boyishness, and with their fundamental realism. Frankly, they are simply much more instinctual with we are, and this includes a spontaneity which you just have to be prepared for. (Windisch, 1946: 88)

Thus Germans' concern with their own identity may be one reason that their perception of the Americans often concentrated on specific character traits. This attention tells us more about the Ciermans than about the Americans. The Western Germans' identity is an essential part of their dialogue with the Americans. We can call this dialogue 'Rehabilitation by Americanisation'. The Americanisation of Western Germany is an inevitable result of German history and a constituent of German identity, which had to be reestablished in the early post-war period. The discourse of German identity forms a major component of the German discourse of guilt. The subject of this discourse is the essential substance of German identity. On the one hand, the members of the élites obviously knew abouc the criminality of the former Nazi regime and they were also aware that a different attitude, a different mentalite within the German people could have prevented the disaster of National Socialism; they realised the fact that resistance to the Nazi regime was too weak, and cowardice, ohedience and militarism were too strong.

On the other hand, they, the Germans, were hated and despised throughout the world. So the élites' aim was to achieve the rehabilitation of the German people. Therefore, their objective was to convince the world and their compatriots of the 'other', the 'better' Germany. This meant the establishment (or reestablishment) of a Cerman identity that had nothing to do with National Socialism, the crimes of Hitier, Himmler and Goebbels, the concentration camp beasts of Bergen - Belsen and Auschwitz, Kramer and $H o ̈ B$, but which has to do, instead, with Schiller, Goethe ond Lessing, with Bach and Beethoven, and with the values of the Christian West. My thesis is that the European tradition represented by these figures was perceived as an integral part of American culture, which facilitated Germany's post-war turn to the USA. They felt that they had in fact already long been part of this world. The conviction that America was rooted in European and especially in German culture, in literature and music, philosophy and scholarship, was one of the gates through which the Germans let the Americans in. Whereas Bolshevism appeared strangely 'Asiatic', Americanisation was, in a sense, a synonym for the well known and the familiar. 
We can thus see that the Americanisation of Germany in the early post-war period was not only a condition of Germany's rehabilitation as one of the free democracies, but was also a way not so much of rapidly camouflaging, than of compensating for German guilt. In this respect, Americanisation meant becoming modern, open, tolerant, democratic. Americanisation can be seen as a way of coming to terms with the past. The famous German psychoanalysts, Alexander and Margarete Mitscherlich, who examined the Germans' inability to mourn in the aftermath of the collapse of Nazism, were suspicious of the intensity with which the Germans turned towards the west so soon after they had supported a political regime of intolerance and inhumanity. They discovered a basic attitude that could be reconciled with both National Socialism and the democracy of the Federal Republic. They termed this attitude the 'idealism of the political guardians', a faith in authority that was far more steadlast than was necessary. "By these identifications we reestablish our badly damaged self-image. This gives us a feeling of security' (Mitscherlich \& Mitscherlich, 1990: 80 81), the Mitscherlichs state. In other words, Ciermany had found a new father figure in the form of the democratic state.

The Germans' desire for international recognition, for an escape from provincialism, for development towards a modern society and for reconstruction was immense. This desire complied with American policies towards Germany. Its components were denazification, demilitarisation and democratisation. They pursued specific cultural policies to prevent Germany's regression into aggressive nationalism and militarism, and thus to stop Germans from becoming a danger to the world again. The German aspect of American foreign policy became a success story -. also in terms of language. It seems that the desire to avoid anything that smacks of nationalism has affected language attitudes in the German speech-community. The time of fetishising language as a national treasure to be preserved was definitely over. Ruth Andreas-Friedrich wrote in her diary on the 22 of June 1945: 'Communication means team-work. Tcam-work means construction.' In the original version: 'Verständigung heißt team-work. Team-work heißßt Aufbau' (Andreas-Friedrich, 1986: 70): the Americanisation of the Germans and the German language in a nutshell.

\section{Conclusion}

In the foregoing discussion, I have explained changes in linguistic usage as the result not only of specific political and social circumstances, but also as an expression of the constitution of a new German identity. Summing up, we can say that the Americanisation of the German language was caused by a complex of factors:

(1) The American occupation of and influence on Germany functioned as a channel for linguistic influence.

(2) The Germans' attitude towards the Americans was also responsible for linguistic influence: the majority of the German people, average citizens and members of the élites, had rriendly sentiments and feelings of respect 
towards America, although there were sporadic anti-American remarks by post-war commentators." There was relief during the American occupation and contentment with the American occupiers. In contrast to their eastern compatriots, the Germans in the American zone knew that they had got off lightly. The Germans' experience of the Americans was basically positive, resulting in a shared German-American will for cooperation. So the Americanisation of German society and the German language was well prepared on all social levels. On the level of everyday life as well as on the official level, on the level of the average citizen as well as on the level of the élite - everyone benefited from America's good deeds.

(3) The lost war and the consciousness of the immensity of German guilt forced the Germans to adopt a new identity: the concept of German national identity was well suited to the appropriation of American culture. The Americanisation of the German language in the early postwar era is part of the German discourse of guilt - as this discourse has a great deal to do with German identity. We can talk about the creation of identity through linguistic openness. Since 1945, there has been an active desire to absorb the American language by post-war Germans of all social strata. As Americanisation is an activity carried out by the Germans and not by the Americans, it expresses a need to 'catch up' with America in the sphere of everyday life, as well as in higher cultural, scientific and technological fields. Germans on all social levels were ready for Anericanisation.

\section{Correspondence}

Any correspondence should be directed to Dr Heidrun Kämper, Institut für deutsche Sprache, R 5, 6-13, D-68161 Mannheim, Germany (Kaemper@ ids-mannhein.de).

\section{Notes}

1. Monfalite' is the 'ensemble of ways of thinking and the contents of thought that are characteristic of at particuiar collective at a particular time' (Dinzelbacher, 1993: 21).

2. Sex Dinzelbacher (1993: 21): 'Montalitc manifosts itself in actions' and 'every action says something about the montolite that informs it. But this mentalite is only accessible to us by means of the interpretation of the traces of these actions' (p. 25).

3. The Brockhaus of 1838 notes: 'Democracy' as a more of government by the people, is properly at home in American' (Conversations-Lexicon, 1838: 914). This perception was still valid in the post-war period.

t. The dates of the examples do not necessarily indicate their first documented use. Rather, in some cases they reflect an increasing usage at the time indicated. Thus, Americanisation with reference to individual words means not only their first appearance in German, but also a politically or socially dictated increase in their frequency of use at a later point in time. For most of the examples see AnglizismenWorterbucl (1993 1946). See also: Carstensen \& Galinsky (1963): Carstensen (1965); Viereck (1984); Yang (1990).

5. They were exemplary denocnats, and it is thanks to them that the democratic system beciune anchored in Western German society. Dimokntio was a slogan and a declaration: Tolerance with regard to democracy means the inevitable victory of the intolerant cnemies of democracy. Whoever says no to democracy comnot be full citizen in the democracy', proclaimed Kurt Schumacher in 1945 
(Schumacher, 1945: $261 \mathrm{f}$ ). A participant in the first German Writers' Congress of 1947 displayed considerable emotion when expressing his altitude towards demecracy. Democracy for him was a 'problem' which caused him 'suffering': "The problem, from which we suffer and for which we fight and which is our destiny is the problem of a true democracy' (Hagelstange, 1947: 248).

6. See the contributions in Junker (2001).

7. These key features, such as political immaturity, obedience towards authority, a spirit of subserience, implicit jdealism and an aggressive tendency to believe in the

8. He represented his experiences there in his famous postwar novel Der Iotemanld, written one year after his release in 1939.

9. On the level of official political and economic affairs, the influential figure Wilhelm Röpke, emigrant and then advisor to the chancellor, was a dissenting voice. He deplored the fact that now; at the war's end, Germany alone was blamed, while during the Nazi period, not one of the Allied powers was ready to support the Cerman resistance, although they all knew about the cruelties in the concentration camps. More than this, they even flattered Hitler and made contracts with him, treating him like a scrious statesman (Röpke, 1948).

\section{Reterences}

Act of Surrender (1945) Act of Surrender by Cermany, Signed at Berlin, May 8, 1945. In U.S. Departme'tl of Statc. Docume'nts on Germany, 1944-1985, 14.

Adenauer, K. (1949a) Regierungserklärung vom 20. September 1949. In Pulte, P. (ed.) Regierungserklärungen 1949-1973. Berlin, New York: de Gruyter. 1973.

Adenauer, K. (194\%) Erste Regierungserklärung vom 20. September 1949. In Schwarz, H.-P. (ed.) Reden 1917 -1967. Eine Ausainlfl. Stuttgart: Deutsche Verlagsanstalt. 1975. Andreas-Friedrich, R. (1986) Schauplaiz Berlin. Tingcbucliaufzeichmingen 1945 bis 1948.
Frankfurt/M.: Suhrkamp.

Anglizismen-Wörterbuch (1993-1996) Der Einfluss des Englischen auf den deutschen Wortschaty nach 1945. 3 vols. Berlin: de Gruyter.

Benz, W. (ed.) (1984) Ludwoig Vambel. Zusammenbruch und Wiedermufaur. Ein Tagebuch der Wirtschuft 1945-1949. München: Oldenbourg Verlag.

Brecht, B. (1948) Freiheit und Democracy. In Os! und West. Buitrïge zur kulturellen und politische'l Fragen der Ze'il. Berlin 1948 (10), S. $36-41$.

Büchmaın, G. (2001) Gefliggelte. Worte. Der Klassische Zifatenschatz gesammelt und erläutert ron Georg Büchmann. 42. Auflage. München: Ullstein.

Carstensen, B. and Galinsky, H. (1963) Amerikanisme's der deulschen Ge'gemumissprache. Heidelberg: Winter.

Carstenssen, B. (1965) Englische Einfliisse auf dic deutsche Sirnche noch 1945. Heidelberg: Winter.

Conversations-Lexicon (1838) Brockhnus Coniersations-Lexicon. Vol. 1. Leipzig: Brockhaus.

Dinzelbacher, P. (1993) Zur Theorie und Praxis der Mentalitälsgeschichte. In Dinzelbacher, P. (ed.) Europäische Mentalititsgeschichte. Hauthemen in Einzeldarsfellumgen (PP. XV $X X X V I I)$. Stuttgart: Kröner.

Galinsky, H. (1977) Amerikanisch-englische und gesamtenglische Interferenzen mit dem Deutschen und anderen Sprachen der Gegenwart. In H. Kolb and H. Lauffer (eds) Sprachliche Interferenz. Festsclurift fïr Werncr Betz zum 65. Gelurtsing (pp. 463517). Tübingen: Niemeyer.

Hagelstange, R. (1947) [Diskussionsbeitrag]. In U. Reinhold, D. Schlenstedt and H. Tanneberger (eds) Ersier Dewtscher Schriflstellerkongrofs. 4.-8. Okloler 1947 (pp. 248-253). Berlin: Aufbau Verlag. 1997.

Hermanns, F. (1995) Sprachgeschichte als Mentalitätsgeschichte. Uberlegungen zu Sinn und Form und Cegenstand historischer Semantik. In $\wedge$. Gardt, K.J. Maltheier and $O$. Reichmann (eds) Sprochgesthichle' de's Nenhochleulschen. Gege'nstäinde, Methode', Theoric"n (pp. 69-101). Tübingen: Max Niemeyer Verlag. 
Heuss, Th. (1946) Kapitulation. 9. Mai 1946. In E. Pikart (ed.) Anfzeichnungen 1945-1947. Tübingen: Verlag Rainer Wunderlich Verlag Hermann Leins.

Heuss, Th. (1955) An die eliemaligen Hohen Kommissare. 5. Mai 1955. In Reden der deutschen Bumfesprösidenten Henss, Lübke, Heinemunn, Scheel (pp. 5-10). München/ Wien: Carl Hanser Verlag 1979.

Jaspers, K. (1945) Geleitwort. Die Wandlung 1 ( 3).

Junker, D. (ed.) (2001) Die USA und Drutschland im Zeitalter des Kalten Krieges 1945-1990. Ein Hantbuch. Vol. I 1945-1968, Vol. II 1968-1990. Stuttgart, München: Deutsche Verlagsanstalt.

Kämper, H. (2001) Die Amerikanisierung der deutschen Sprache. In D. Junker (ed.) Dic USA und Dentschland im Zeitalter des Kalten Krieges 1945-1990. Band [1 1968 -1990 (pp. 496-506). Stuttgart, München: Deutsche Verlagsanstalt.

Kämper, H. (2003) Von zeitbedingten und ewigen Deutschen. Der Identitätsdiskurs in der frühen Nachkriegszeit und seine argumentative Struktur. In $\mathrm{M}$. Wengeler (ed.) Deutsche Sprachgeschichtc mach 1945. Diskurs- und kulturgeschichtliche Perspektiven. Beiträge zu ciner Tagung anlässlich der Enteritierung Georg Stötzels (pp. 338-363). Hildesheim, Zürich, New York: Olms.

Koeppen, W. (1980) Thulien im Gras. Frankfurt/M.: Suhrkamp.

Kuhlemann, F.-M. (1996) Mentalitätsgeschichte. Theoretische und methodische Überlegungen am Beispiel der Religion im 19. und 20. Jahrhundert. In W. Hardtwig and H.-U. Wehler (eds) Kulturgeschichte Heute (pp. 182-211). Göttingen: Vandenhoeck \& Ruprecht.

Mitscherlich, A. and Mitscherlich, M. (1990) Die Unfähigkeit zu Irauem. Grundlagen kollekfiuen Verialtens. München, Zürich: Piper Verlag.

Redskob, E. (1947) [Diskussionsbeitrag] In U. Reinhold, D. Schlenstedt and H. Tanneberger (eds) Erster Deirtscher Schriftstellerkongref3. 4.-8. Oklober 1947 (p. 451). Berlin: Aufbau Verlag. 1997.

Röpke, W. (1948) Dic deutsche Frage, Erlenbach-Zürich: Eugen Rentsch Verlag.

Schumacher, K. (1945) Politische Richtlinien für die SPD in ihrem Verhältnis zu den anderen politischen Faktoren. In W. Albrecht (ed.) Kurt Schwmacher. Reden - Schriften - Korrespromienzes 1945-52 (pp. 256-286). Berlin, Bonn: Verlag J. H. W. Dietz Nachf.

Viereck, W. (1984) Britisches Englisch und Amerikanisches Englisch/Deutsch. In W. Besch, O. Reichmann and S. Sonderegger (eds) Sprachgeschichte. Ein Handluach zur Geschichte ter deulscherr Sprache und ihter Erforschung, Vol. 2. Berlin: de Gruyter.

Wiechert, E. (1949) Jalsre wnd Zaiten. Erinnernugen. Erlenbach-Zürich: Eugen Rentsch Verlag.

Windisch, H. (1946) Fïhrer unt Verführte. Eine Annlyse dettschen Schicksals. Seebruck am Chiemsee: Heering-Verlag.

Yang, W. (1990) Anglizismen in Deutschen: Am Beispicl des Nachichtenmagazins, Der Spiegel'. Tübingen: Niemeyer.

Ziegelschmid, A.J.F. (1935) Englisch-amerikanischer Einfluss auf den Wortschatz der deutschen Sprache der Nachkriegszeit. Joumnl of English and Gommic Philology 34 (1). 25. 